\title{
AKTIVITAS ANTIDIARE EKSTRAK ETANOL DAUN SUJI (Dracaena angustifolia Roxb)
}

\author{
ANTIDIARRHEAL ACTIVITIES OF ETANOL EXTRACT SUJI LEAF \\ (Dracaena angustifolia Roxb)
}

\author{
Ika Kurnia Sukmawati ${ }^{1}$, Elin Yulinah Sukandar ${ }^{2}$, Neng Fisheri Kurniati ${ }^{2}$ \\ ${ }^{1}$ Sekolah Tinggi Farmasi Bandung, Jl. Soekarno Hatta No. 754 Cibiru, Bandung, Indonesia \\ ${ }^{2}$ Sekolah Farmasi, Institut Teknologi Bandung, Jl. Ganesha No. 10, Bandung, Indonesia \\ Email: Ika.kurnia@stfb.ac.id (Ika Kurnia Sukmawati); \\ elin@fa.itb.ac.id (Elin Yulinah Sukandar); nfkurniati@fa.itb.ac.id (Neng Fisheri Kurniati)
}

\begin{abstract}
ABSTRAK
Penyakit diare masih menjadi masalah kesehatan terutama di berbagai negara berkembang termasuk Indonesia. Secara tradisional masyarakat telah menggunakan daun suji (Dracaena angustifolia Roxb L.) untuk mengatasi berbagai gangguan pencernaan termasuk diare. Tujuan dari penelitian ini adalah untuk menguji aktivitas antidiare dan antibakteri ekstrak etanol daun suji. Ekstraksi dilakukan dengan metode refluks menggunakan pelarut etanol $96 \%$. Uji aktivitas antimikroba dilakukan secara in vitro dengan menggunakan metode broth microdilution terhadap ekstrak. Mikroba uji yang digunakan adalah Escherichia coli, Shigella dysenteriae, Shigella flexneri, dan Salmonella typhi. Dilakukan uji antidiare pada hewan uji yang diinduksi minyak jarak. Sediaan uji diberikan satu jam sebelum induksi kemudian dilakukan pengamatan terhadap feses (frekuensi, konsistensi, dan berat). Metode waktu lintas usus juga dilakukan pada percobaan ini dengan prinsip membandingkan usus yang dilalui marker dengan panjang usus seluruhnya. Dari pengujian antibakteri, ekstrak daun suji mempunyai kemampuan penghambatan pada bakteri Shigella dysenteriae, Shigella flexneri, Eschericia coli, dan Salmonella typhi, dengan KHM (Konsentrasi Hambat Minimum) berturut-turut $25000 \mu \mathrm{g} / \mathrm{mL}, 25000 \mu \mathrm{g} / \mathrm{mL}, 12500 \mu \mathrm{g} / \mathrm{mL}$, dan >25000 $\mu \mathrm{g} / \mathrm{mL}$. Dari hasil uji aktivitas antidiare daun suji, kelompok dosis ekstrak yang mempunyai aktivitas dalam memproteksi diare oleh minyak jarak yaitu dosis 50 $\mathrm{mg} / \mathrm{kgBB}$, dosis ini dapat menurunkan frekuensi defekasi berbeda bermakna dibanding kelompok kontrol $(p<0,05)$, dosis $25 \mathrm{mg} / \mathrm{kgBB}$ dan $100 \mathrm{mg} / \mathrm{kgBB}$ dapat meningkatkan konsistensi dan menurunkan berat feses.
\end{abstract}

Kata kunci: suji, Dracaena angustifolia Roxb, antimikroba, antidiare.

\section{ABSTRACT}

Diarrhea is defined as an increased defecation (bowel movements) more than usual/more than three times a day, accompanied by consistent changes in stool (to liquid) with or without blood. Diarrhea still becomes the main health problem especially 
in several developing countries including Indonesia. Dracaena angustifolia Roxb have been used as traditional plan to treat various gastrointestinal tract disorders including diarrhea. The purpose of this study was to evaluate antidiarrheal activity of extract suji leaf (Dracaena angustifolia Roxb). The extraction was conducted using reflux method with ethanol $96 \%$ as solvent. In vivo antidiarhheal activity was evaluated by administrating castor oil into mice as an induction method. Extract was given one hour before castor oil administration. Furthermore, frequency, consistency, and weight of feces was observed. Intestinal transit method was also performed in this experiment by comparing the length of the intestinal through by marker with the total length of the intestine. From the tests of antibacterial extracts of leaves suji has the capability of inhibition on the bacteria Shigella dysenteriae, Shigella flexneri, Escherichia coli, and Salmonella typhi, the MIC consecutive 25000 ppm, 25000 ppm, 12500 ppm and >25000 ppm. Antidiarrheal activity of test results suji leaf extract dose group which has activities in protecting diarrhea by castor oil is a dose of $50 \mathrm{mg} / \mathrm{kg}$, these doses can reduce the frequency of defecation was significantly different than the control group $(p<0.05), a$ dose of $25 \mathrm{mg} / \mathrm{kgBB}$ and $100 \mathrm{mg} / \mathrm{kgBB}$ can improve the consistency and weight of stool.

Key words: antidiarrheal, suji, Dracaena angustifolia Roxb. 


\section{Pendahuluan}

Diare adalah suatu gejala klinik gangguan pada saluran pencernaan dimana konsistensi tinja berbentuk cairan atau setengah cairan dan frekuensi terjadinya defekasi lebih sering dari keadaan normal sekitar empat sampai lima kali sehari, dengan demikian kandungan air pada tinja lebih banyak dari normal yaitu 200 g/hari. Karena berat feses sebagian besar ditentukan oleh air feses, kebanyakan kasus diare disebabkan oleh gangguan air dan elektrolit di usus. Penyebab diare adalah: peningkatan tekanan osmotik di dalam usus sehingga menyebabkan retensi air didalam lumen, sekresi elektrolit dan air yang berlebihan ke dalam lumen usus, eksudasi protein dan cairan dari mukosa, peningkatan motilitas usus sehingga mempercepat transit (Goodman dan Gilman, 2007).

Mekanisme patofisiologis yang mengganggu keseimbangan air dan elektrolit yang mengakibatkan terjadinya diare, yaitu: perubahan transport ion aktif yang disebabkan oleh penurunan absorpsi natrium atau peningkatan sekresi klorida, perubahan motilitas usus, peningkatan osmolaritas luminal, peningkatan tekanan hidrostatik jaringan. Sehingga diare dapat dikelompokkan secara klinik yaitu: diare sekretori, terjadi ketika senyawa yang strukturnya mirip meningkatkan sekresi atau menurunkan absorpsi air dan elektrolit dalam jumlah besar; diare osmotik disebabkan oleh absorpsi zat-zat yang mempertahankan cairan intestinal; diare exudatif disebabkan oleh penyakit infeksi saluran pencernaan yang mengeluarkan mucus, protein, atau darah ke dalam saluran pencernaan; motilitas usus dapat berubah dengan mengurangi waktu kontak di usus halus, pengosongan usus besar yang premature dan pertumbuhan bakteri yang berlebihan (Sukandar dkk., 2009).

Tujuan terapi pengobatan diare adalah untuk mengatur diet, mencegah pengeluaran air berlebihan, elektrolit, dan gangguan asam basa, menyembuhkan gejala, mengatasi penyebab diare, dan mengatur gangguan sekunder yang menyebabkan diare. Obat-obat yang digunakan dalam pengobatan diare dikelompokkan menjadi beberapa kategori yaitu antimotilitas, adsorben, antisekresi, antibiotic, enzim, dan mikroflora usus. (Wells dkk., 2014). 
Pengobatan diare kronik sering menggunakan kombinasi antara pengobatan simptomatis dan pengobatan kausatif. Tanaman obat yang mengandung zat-zat seperti tanin, tanalbumin, merupakan senyawa antidiare yang bekerja sebagai adstringen sedangkan tanaman obat yang mengandung papaverin, glikosida, alkaloid, dan minyak atsiri mempunyai sifat antidiare yang kerjanya menekan peristaltik usus (Oswald dkk., 1982).

Masyarakat secara tradisional telah menggunakan beberapa jenis tanaman untuk mengobati diare, dan pengetahuan ini biasanya diwariskan kepada generasi berikutnya. Daun suji merupakan salah satu tanaman yang digunakan secara empiris untuk pengobatan diare. Daun suji biasa digunakan sebagai pewarna karena memberi warna hijau yang lebih pekat daripada daun pandan wangi yang juga merupakan sumber warna hijau, tetapi tidak memiliki aroma. Tumbuhan daun suji memiliki rasa yang tidak pahit, berbau harum, dan bersifat dingin. Beberapa, senyawa kimia yang terdapat dalam daun suji di antaranya saponin, polifenol dan flavonoid. Bagian daun, akar, dan batang dapat dimanfaatkan untuk mengobati beberapa penyakit sebagai berikut: disentri dan beri-beri, kencing nanah, nyeri lambung, nyeri haid, dan penawar racun (Depkes RI, 1986). Untuk mendapatkan informasi yang lebih luas maka dilakukan uji aktivitas antidiare ekstrak dan fraksi daun suji (Dracaena angustifolia Roxb) secara in vivo dan in vitro.

\section{Metode Penelitian}

Penelitian ini melalui beberapa tahap utama yaitu tahap penyiapan bahan, karakterisasi simplisia, penapisan fitokimia, ekstraksi, pengujian aktivitas antibakteri dengan metoda broth microdilution, kemudian pengujian aktivitas antidiare menggunakan metoda proteksi terhadap minyak jarak dan metoda transit intestinal usus.

Pengumpulan dan Penyiapan Bahan

Bahan berupa daun suji (Dracaena angustifolia Roxb) diperoleh dari daerah Cibiru, Kabupaten Bandung Timur. Untuk mengetahui kebenaran tumbuhan uji yang digunakan maka dilakukan determinasi tanaman dengan cara membandingkan bahan yang dideterminasi dengan daftar pustaka. Determinasi tanaman dilakukan di Herbarium Bandungense, Program Studi Biologi, Sekolah IImu dan Teknologi Hayati, Institut Teknologi Bandung. Daun 
kemangi dikeringkan menggunakan oven pada suhu $50 \stackrel{\circ}{ } \mathrm{C}$.

\section{Ekstraksi}

Pembuatan ekstrak dilakukan dengan cara panas, yaitu metode refluks menggunakan pelarut etanol 96\%. Daun suji kering yang telah ditumbuk terlebih dahulu ditimbang sebanyak beberapa gram. Kemudian dimasukan ke dalam labu dengan pelarut etanol 96\%. Ekstrak hasil refluks dikumpulkan, kemudian ekstrak dikentalkan dengan menggunakan rotary evaporator.

Uji Aktivitas Antibakteri

Alat dan media disterilisasi dengan autoklaf selama 15 menit. Sebanyak $100 \mu \mathrm{L}$ MHB (Mueller Hinton Broth) dimasukan dalam pelat mikro pada kolom pertama sebagai kontrol negatif. Suspensi bakteri sebanyak $5 \mu \mathrm{L}$ ditambahkan ke dalam $10 \mu \mathrm{L}$ MHB, kemudian diaduk dengan alat vortex. Sebanyak $100 \mu \mathrm{L}$ campuran tersebut dimasukan dalam pelat mikro pada kolom kedua sampai kedua belas. Pada kolom kedua belas, ditambahkan $100 \mu \mathrm{L}$ larutan antibiotik/ekstrak dengan konsentrasi tertentu kemudian dihomogenkan. Dari kolom kedua belas, diambil $100 \mu \mathrm{L}$ kemudian dipindahkan ke kolom sebelas. Pengenceran terus dilakukan sampai pada kolom ketiga yang akan memiliki konsentrasi terkecil yaitu pada kolom ketiga. Pelat di inkubasi pada suhu ruangan selama $3 \times 24$ jam kemudian diamati bagian yang jernih (tidak ada pertumbuhan mikroba). Nilai KBM (Konsentrasi Bunuh Minimum) ditentukan setelah larutan uji tersebut ditumbuhkan kembali pada medium MHA (Mueller Hinton Agar). Sebanyak 5 $\mu \mathrm{L}$ alikuot dari setiap bagian yang jernih dipindahkan dalam MHA dan diinkubasi pada suhu $25{ }^{\circ} \mathrm{C}$ selama $3 \times 24$ jam kemudian diamati. KHM didefinisikan sebagai konsentrasi terendah dari senyawa yang dapat menurunkan $80 \%$ atau lebih pertumbuhan dibandungkan dengan control (NCCLS). Sedangkan KBM didefinisikan sebagai konsentrasi terendah yang menunjukan tidak adanya pertumbuhan atau hanya tumbuh satu koloni. Mikroba yang digunakan adalah Escherichia coli, Shigella dysenteriae, Shigella flexneri, dan Salmonella typhi.

\section{Uji Aktivitas Antidiare}

1. Metode proteksi terhadap diare oleh minyak jarak

Mencit putih jantan swiss Webster sehat dengan bobot 20-25 g digunakan sebagai hewan uji. Hewan yang digunakan untuk percobaan memiliki feses normal. Satu jam sebelum percobaan dimulai mencit 
dipuasakan makan dan minum. pada tiap mencit diamati selang 30 Sediaan uji diberikan dengan cara oral menit sampai 4 jam, kemudian selama $0,5 \mathrm{~mL} / 20 \mathrm{~g}$ bobot badan mencit, satu jam sampai 5 jam setelah kemudian ditempatkan di dalam pemberian Oleum ricini. Parameter bejana individual yang beralaskan yang diamati meliputi frekuensi kertas saring pengamatan. Satu jam defekasi, konsistensi, berat feses, setelah perlakuan diberikan $0,75 \mathrm{~mL}$ onset, dan durasi diare.

minyak jarak. Respon yang terjadi

Tabel 1. Pembagian kelompok berdasarkan sediaan yang diberikan dan jumlah dosisnya untuk metoda proteksi terhadap diare oleh minyak jarak

\begin{tabular}{lcc}
\hline Sediaan Uji & Kelompok & Dosis (mg/kgbb) \\
\hline Minyak Jarak & 1 & $0,75 \mathrm{~mL} / 20 \mathrm{gBB}$ \\
Ekstrak etanol daun suji & 2 & $25 \mathrm{mg} / \mathrm{kgBB}$ \\
& 3 & $50 \mathrm{mg} / \mathrm{kgBB}$ \\
& 4 & $100 \mathrm{mg} / \mathrm{kgBB}$ \\
Loperamid & 5 & $2 \mathrm{mg} / \mathrm{kgBB}$ \\
\hline
\end{tabular}

2. Metode transit intestinal

Mencit putih swiss Webster jantan dewasa sehat dengan berat 20 25 g digunakan sebagai hewan uji. Hewan percobaan dipuasakan selama lebih kurang 18 jam, minum tetap diberikan. Setelah ditimbang, hewan dikelompokkan secara acak ke dalam 14 kelompok.

Pada waktu $t=0$, sediaan $u j i$ diberikan secara oral $0,5 \mathrm{~mL} / 20 \mathrm{~g}$ bobot badan mencit. Setelah $t=45$ menit, mencit diberikan tinta cina 0,1 $\mathrm{ml} / 10 \mathrm{~g}$ secara oral. Pada $\mathrm{t}=65$ menit, mencit dikorbankan secara dislokasi tulang leher.

Usus mencit dikeluarkan secara hati-hati sampai terenggang. Panjang usus yang dilalui marker tinta mulai dari pylorus samai ujung akhir (yang berwarna hitam) diukur. Demikian pula panjang seluruh usus dari masing-masing hewan dihitung rasio normal jarak yang ditempuh marker terhadap panjang usus seluruhnya. 
Tabel 2. Pembagian kelompok berdasarkan sediaan yang diberikan dan jumlah dosisnya untuk metoda transit intestinal

\begin{tabular}{lcc}
\hline Sediaan Uji & Kelompok & Dosis (mg/kgBB) \\
\hline Normal & 1 & $0,75 \mathrm{~mL} / 20 \mathrm{gBB}$ \\
Ekstrak etanol daun suji & 8 & $25 \mathrm{mg} / \mathrm{kgBB}$ \\
& 9 & $50 \mathrm{mg} / \mathrm{kgBB}$ \\
& 10 & $100 \mathrm{mg} / \mathrm{kgBB}$ \\
Loperamid & 17 & $2 \mathrm{mg} / \mathrm{kgBB}$ \\
\hline
\end{tabular}

\section{Hasil dan Pembahasan}

Daun suji diperoleh dari daerah Cibiru, Bandung. Dari data determinasi yang dilakukan di Herbarium Bandungense, Program Studi Biologi, Sekolah IImu dan Teknologi Hayati, Institut Teknologi Bandung diperoleh informasi bahwa tanaman uji yang digunakan merupakan daun suji (Dracaena angustifolia Roxb).

Daun suji dibersihkan dari bagian akar dan daun yang telah menguning kemudian dilakukan pencucian. Pencucian menggunakan air mengalir, tujuannya agar seluruh kotoran yang melekat terutama bahan-bahan yang berasal dari tanah dapat hilang. Selanjutnya dilakukan perajangan. Tujuan dilakukannya perajangan adalah untuk memperluas permukaan. Semakin luas permukaan maka bahan baku akan semakin cepat kering. Pengeringan dilakukan dengan cara di oven pada suhu 50 ㄷ yang bertujuan untuk menurunkan kadar air sehingga bahan baku tidak mudah ditumbuhi kapang dan bakteri.

Hasil ekstraksi dengan pelarut etanol 95\% diperoleh ekstrak etanol daun suji, dari satu kilogram simplisia diperoleh ekstrak kental 192,19 gram. Metode ekstraksi yang dipilih adalah metode refluks karena merupakan metoda ekstraksi cara panas yang memiliki keuntungan dalam meningkatkan kelarutan zat, sehingga waktu ekstraksi dapat lebih singkat. Pelarut yang digunakan untuk ekstraksi adalah etanol yang merupakan pelarut universal. Etanol mampu menarik berbagai macam senyawa dalam simplisia, sebagian besar senyawa polar dan sebagian kecil senyawa nonpolar.

Penapisan fitokimia dilakukan untuk mengetahui golongan kandungan metabolit sekunder yang terkandung dalam simplisia, ekstrak etanol dan fraksi terpilih dari tanaman uji. Hasil pengujian penapisan dapat dilihat pada Tabel 3. 
Tabel 3. Hasil skrining fitokimia ekstrak etanol daun suji

\begin{tabular}{ccc}
\hline No & Golongan & Sampel Ekstrak \\
\hline 1 & Alkaloid & + \\
2 & Flavonoid & + \\
3 & Tanin & + \\
4 & Saponin & - \\
5 & Triterpenoid & + \\
6 & Steroid & + \\
7 & Quinon & - \\
\hline Keterangan: (+) Terdeteksi &
\end{tabular}

Golongan senyawa yang diduga

mempunyai efek antidiare adalah tanin dan alkaloid dimana tanin bersifat adstringensia yang menciutkan selaput lendir usus sehingga bersifat obstipansia, dan alkaloid mempunyai sifat antidiare yang kerjanya menekan peristaltik usus. Sedangkan golongan senyawa yang diduga mempunyai efek antibakteri adalah alkaloid, tanin, dan flavonoid, dimana alkaloid sebagai antibakteri mempunyai gugus aromatik yang dapat mempengaruhi DNA bakteri sehingga menyebabkan terhambatnya pertumbuhan bakteri, sedangkan pada flavonoid memiliki mekanisme kerja antibakteri diduga karena kemampuannya membentuk kompleks dengan protein ekstraseluler sehingga dapat merusak membran sel bakteri diikuti dengan keluarnya senyawa intraseluler, semakin lipofil suatu flavonoid maka kemampuannya merusak membran sel bakteri akan semakin besar.

Pengujian Aktivitas Antibakteri

Diare dapat disebabkan oleh bakteri (diare sekretori) sehingga perlu dilakukan uji aktivitas antibakteri dari ekstrak uji. Ada empat macam bakteri yang digunakan antara lain Shigella dysenteriae, Shigella flexneri, Eschericia coli, dan Salmonella typhi, dimana bakteri-bakteri tersebut merupakan bakteri penyebab penyakit saluran cerna. Uji aktivitas antimikroba terhadap bakteri penyebab diare dilakukan dengan menggunakan metode broth mikrodilution, diperoleh hasil seperti yang tertera pada Tabel 4 .

Pada pengujian aktivitas antibakteri, media yang digunakan untuk menentukan KHM yaitu MHB sedangkan untuk pengujian 
menentukan KBM digunakan media MHA. Pembanding yang digunakan adalah tetrasiklin. Ekstrak etanol daun suji dilarutkan dengan DMSO (dimethyl sulfoxide), karena pelarut ini dapat melarutkan senyawa polar maupun senyawa nonpolar di dalam ekstrak tanpa mempengaruhi aktivitas ekstrak tersebut. Pada percobaan ini digunakan 10 konsentrasi dari pengenceran bertingkat ekstrak daun kemangi di mulai dari 1024 ppm, 512 ppm, 256 ppm, 128 ppm, 64, ppm, 32 ppm, 16 ppm, 8 ppm, 4 ppm, 2 ppm. Kemudian ditingkatkan lagi ke konsentrasi yang lebih tinggi mulai dari 3125 ppm, 6250 ppm, 12500 ppm, 25000 ppm. Uji kekeruhan dilakukan berdasarkan Mc Farland skala $0,5 \mathrm{CFU} / \mathrm{mL}$ yang setara dengan jumlah bakteri sejumlah $10^{8}$ $\mathrm{CFU} / \mathrm{mL}$, menghasilkan absorban pada panjang gelombang $530 \mathrm{~nm}$ sebesar $0,08-0,10$ (NCCLS, 2003).

Tabel 4. Hasil penentuan nilai KHM dan KBM ekstrak daun suji terhadap mikroba uji

\begin{tabular}{lcccc}
\hline \multirow{2}{*}{ Mikroba } & \multicolumn{2}{c}{ EDS $(\mu \mathrm{g} / \mathbf{m L})$} & \multicolumn{2}{c}{ Tetrasiklin $(\mu \mathrm{g} / \mathbf{m L})$} \\
\cline { 2 - 5 } & KHM & KBM & KHM & KBM \\
\hline S dysenteriae & 25000 & $>25000$ & 16 & 16 \\
S flexneri & 25000 & $>25000$ & 16 & 32 \\
S typhi & 12500 & $>25000$ & 16 & 16 \\
E coli & $>25000$ & $>25000$ & 64 & 64 \\
\hline
\end{tabular}

Keterangan: EDS $=$ Ekstrak daun suji.

Hasil yang diperoleh menunjukkan bahwa ekstrak yang diujikan kurang bisa memberikan aktivitas antibakteri yang baik jika akan digunakan sebagai obat karena KHM yang diperoleh $>512 \mu \mathrm{g} / \mathrm{mL}$. Pada daun suji didapat nilai KHM terhadap Salmonella typhi sebesar $12.500 \mu \mathrm{g} / \mathrm{mL}$, sedangkan KHM untuk Shigella flexneri, Shigella dysenteriae, dan Eschericia coli adalah $25.000 \mu \mathrm{g} / \mathrm{mL}$. Nilai KBM dari ekstrak etanol daun suji untuk semua bakteri uji >25000. Dari penelitian ini dapat dilihat daun suji kurang baik penghambatannya terhadap keempat bakteri tersebut, dibandingkan dengan tetrasiklin sebagai pembanding.

Pada metode mikrodilusi, jika ekstrak menghasilkan KHM kurang dari $100 \mu \mathrm{g} / \mathrm{mL}$, maka aktivitas antimikroba bisa dikatakan kuat, jika KHM 100-500 $\mu \mathrm{g} / \mathrm{mL}$ maka aktivitas antimikroba sediaan uji tersebut dikatakan sedang, jika KHM yang diperoleh $500-1000$ 
$\mu \mathrm{g} / \mathrm{mL}$ maka aktivitas antimikrobanya dianggap lemah, dan jika KHM yang diperoleh lebih dari $1000 \mu \mathrm{g} / \mathrm{mL}$ sediaan uji dianggap tidak aktif.

\section{Pengujian Aktivitas Antidiare}

Diare adalah suatu keadaan yang ditandai pengeluaran feses cair atau seperti bubur berulangkali (lebih dari 3 kali sehari) dengan peningkatan konsistensi feses encer yang disebabkan oleh peningkatan motilitas usus karena infeksi bakteri dan berbagai hal lainnya. Oleh sebab itu parameter yang diambil adalah konsistensi feses, frekuensi defekasi, berat feses onset dan durasi diare, kemampuan ekstrak simplisia uji untuk memberikan hambatan terhadap bakteri yang digunakan. Konsistensi feses perlu dilihat untuk mengetahui kemampuan zat uji untuk menurunkan konsistensi feses dengan menurunkan pengeluaran cairan tubuh. Frekuensi defekasi dan transit usus diperlukan untuk melihat kemampuan zat uji dalam menurunkan frekuensi defekasi yang dapat dilihat, berat feses menggambarkan jumlah masa feses yang dikeluarkan.

Penggunaan minyak jarak untuk penginduksi diare pada hewan percobaan dalam penelitian ini adalah karena minyak jarak mengandung trigliserida dari asam ricinoleat yang dihidrolisis dalam usus oleh enzim lipase pancreas menjadi gliserin dan asam ricinoleat sebagai surfaktan anionik, zat ini bekerja mengurangi absorpsi cairan dan elektrolit serta menstimulasi peristaltik usus. Pemilihan loperamid sebagai pembanding karena loperamid dapat memperlambat motilitas intestinal sehingga mampu memperpanjang waktu transit intestinal, menurunkan frekuensi defekasi, meningkatkan viskositas feses, dan mencegah kehilangan cairan dan elektrolit. Bakteri tertentu juga dapat menimbulkan diare sehingga perlu dilakukan pengukuran aktivitas antimikroba. Hasil pengujian aktivitas antidiare ekstrak daun suji ditunjukkan pada Gambar 1 dan Tabel 5. 
Tabel 5. Hasil pengamatan frekuensi defekasi setelah pemberian sediaan

\begin{tabular}{|c|c|c|c|c|c|c|c|c|c|c|}
\hline \multirow[t]{2}{*}{ Kelompok } & \multicolumn{10}{|c|}{ Rata-rata frekuensi defekasi pada menit ke- } \\
\hline & $0-30$ & $30-60$ & $60-90$ & $90-120$ & $120-150$ & $150-180$ & $180-210$ & $210-240$ & $240-270$ & $270-300$ \\
\hline EDS $25 \mathrm{mg} / \mathrm{kgBB}$ & $1,0 \pm 1,22$ & $0,8 \pm 1,3$ & $2,0 \pm 3,94$ & $1,2 \pm 1,64$ & $0,0 \pm 0,0$ & $0,2 \pm 0,45$ & $0,4 \pm 0,89$ & $0,4 \pm 0,89$ & $0,0 \pm 0,0$ & $0,0 \pm 0,00$ \\
\hline EDS 50 mg/kgBB & $4,2 \pm 2,86 *$ & $3,88 \pm 1,64$ & $2,4 \pm 1,52$ & $1,2 \pm 1,64$ & $0,2 \pm 0,45$ & $0,6 \pm 0,89$ & $0,2 \pm 0,45$ & $0,6 \pm 0,89$ & $0,2 \pm 0,45$ & $0,0 \pm 0,0$ \\
\hline EDS $100 \mathrm{mg} / \mathrm{kgBB}$ & $1,2 \pm 0,84$ & $1,0 \pm 1,41$ & $0,8 \pm 1,1$ & $0,6 \pm 0,89$ & $0,4 \pm 0,55$ & $0,6 \pm 0,89$ & $0,0 \pm 0,0$ & $0,8 \pm 1,1$ & $0,0 \pm 0,0$ & $0,0 \pm 0,0$ \\
\hline Kontrol (-) & $1,2 \pm 1,1$ & $1,8 \pm 3,49$ & $0,0 \pm 0,0$ & $0,8 \pm 2,17$ & $2,4 \pm 2,3$ & $1,4 \pm 1,14$ & $1,4 \pm 1,95$ & $0,4 \pm 0,55$ & $0,8 \pm 1,79$ & $0,2 \pm 0,45$ \\
\hline loperamid & $0,4 \pm 0,55$ & $2,2 \pm 3,19$ & $0,4 \pm 0,55$ & $0,8 \pm 1,10$ & $0,6 \pm 1,34$ & $0,4 \pm 0,89$ & $0,8 \pm 1,3$ & $0,2 \pm 0,45$ & $0,2 \pm 0,45$ & $0,2 \pm 0,45$ \\
\hline
\end{tabular}

Keterangan: EDS= Ekstrak Daun Suji, ${ }^{*}=$ berbeda bermakna terhadap kontrol negatif $(p<0,05)$

Tabel 6. Hasil pengamatan konsistensi feses setelah pemberian sediaan

\begin{tabular}{|c|c|c|c|c|c|c|c|c|c|c|}
\hline \multirow[t]{2}{*}{ Kelompok } & \multicolumn{10}{|c|}{ Rata-rata frekuensi defekasi pada menit ke- } \\
\hline & $0-30$ & $30-60$ & $60-90$ & $90-120$ & $120-150$ & $150-180$ & $180-210$ & $210-240$ & $240-270$ & $270-300$ \\
\hline EDS $25 \mathrm{mg} / \mathrm{kgBB}$ & $0,0 \pm 0,0$ & $0,0 \pm 0,0$ & $0,0 \pm 0,0$ & $0,0 \pm 0,00$ & $0,0 \pm 0,0 *$ & $0,2 \pm 0,45$ & $0,0 \pm 0,00$ & $0,0 \pm 0,0$ & $0,0 \pm 0,0$ & $0,0 \pm 0,0$ \\
\hline EDS $50 \mathrm{mg} / \mathrm{kgBB}$ & $0,0 \pm 0,0$ & $0,8 \pm 0,84$ & $1,2 \pm 1,1$ & $1,0 \pm 1,41$ & $0,8 \pm 1,1$ & $0,6 \pm 0,89$ & $0,2 \pm 0,45$ & $0,4 \pm 0,55$ & $0,0 \pm 0,0$ & $0,0 \pm 0,0$ \\
\hline EDS $100 \mathrm{mg} / \mathrm{kgBB}$ & $0,6 \pm 0,89$ & $0,4 \pm 0,89$ & $0,4 \pm 0,89$ & $0,0 \pm 0,00$ & $0,0 \pm 0,0 *$ & $0,0 \pm 0,00$ & $0,0 \pm 0,0$ & $0,0 \pm 0,0$ & $0,0 \pm 0,0$ & $0,0 \pm 0,0$ \\
\hline Kontrol (-) & $0,0 \pm 0,0$ & $0,2 \pm 0,45$ & $0,4 \pm 0,89$ & $1,0 \pm 1,73$ & $1,6 \pm 1,67$ & $1,2 \pm 1,64$ & $0,8 \pm 1,3$ & $1,04 \pm 0,95$ & $0,44 \pm 0,88$ & $0,2 \pm 0,45$ \\
\hline loperamid & $0,2 \pm 0,45$ & $0,2 \pm 0,45$ & $0,6 \pm 0,89$ & $0,0 \pm 0,0$ & $0,0 \pm 0,0^{*}$ & $0,0 \pm 0,0 *$ & $0,0 \pm 0,0$ & $0,0 \pm 0,00$ & $0,0 \pm 0,0$ & $0,0 \pm 0,0$ \\
\hline
\end{tabular}

Keterangan: EDS= Ekstrak daun suji, ${ }^{*}=$ berbeda bermakna terhadap kontrol negatif $(p<0,05), 0=$ tidak ada feses, $1=$ normal, $2=$ keras lembek, 3 = berair massa masih berbentuk, 4 = berair, massa tidak berbentuk.

Tabel 7. Hasil pengamatan berat feses setelah pemberian sediaan

\begin{tabular}{|c|c|c|c|c|c|c|c|c|c|c|}
\hline \multirow[t]{2}{*}{ Kelompok } & \multicolumn{10}{|c|}{ Rata-rata frekuensi defekasi pada menit ke } \\
\hline & $0-30$ & $30-60$ & $60-90$ & $90-120$ & $120-150$ & $150-180$ & $180-210$ & $210-240$ & $240-270$ & $270-300$ \\
\hline EDS 25 mg/kgBB & $0,03 \pm 0,04^{*}$ & $0,08 \pm 0,12$ & $0,08 \pm 0,12$ & $0,07 \pm 0,11$ & $0,0 \pm 0,0$ & $0,08 \pm 0,14$ & $0,02 \pm 0,04$ & $0,0 \pm 0,0$ & $0,02 \pm 0,04$ & $0,0 \pm 0,0$ \\
\hline EDS $50 \mathrm{mg} / \mathrm{kgBB}$ & $0,22 \pm 0,15$ & $0,2 \pm 0,12$ & $0,2 \pm 0,12$ & $0,2 \pm 0,09$ & $0,10 \pm 0,04$ & $0,05 \pm 0,03$ & $0,05 \pm 0,02$ & $0,01 \pm 0,04$ & $0,01 \pm 0,0$ & $0,0 \pm 0,0$ \\
\hline EDS $100 \mathrm{mg} / \mathrm{kgBB}$ & $0,07 \pm 0,06 *$ & $0,08 \pm 0,18$ & $0,06 \pm 0,09$ & $0,08 \pm 0,11$ & $0,03 \pm 0,04$ & $0,06 \pm 0,09$ & $0,0 \pm 0,0$ & $0,18 \pm 0,3$ & $0,0 \pm 0,0$ & $0,0 \pm 0,0$ \\
\hline Kontrol (-) & $0,49 \pm 0,45$ & $0,1 \pm 0,22$ & $0,21 \pm 0,27$ & $0,05 \pm 0,05$ & $0,21 \pm 0,24$ & $0,03 \pm 0,04$ & $0,04 \pm 0,05$ & $0,01 \pm 0,02$ & $0,04 \pm 0,09$ & $0,02 \pm 004$ \\
\hline loperamid & $0,32 \pm 0,40$ & $0,36 \pm 0,48$ & $0,21 \pm 0,41$ & $0,06 \pm 0,14$ & $0,05 \pm 0,1$ & $0,01 \pm 0,02$ & $0,02 \pm 0,04$ & $0,0 \pm 0,00$ & $0,09 \pm 0,17$ & $0,0 \pm 0,0$ \\
\hline
\end{tabular}

Keterangan : EDS $=$ Ekstrak daun suji 


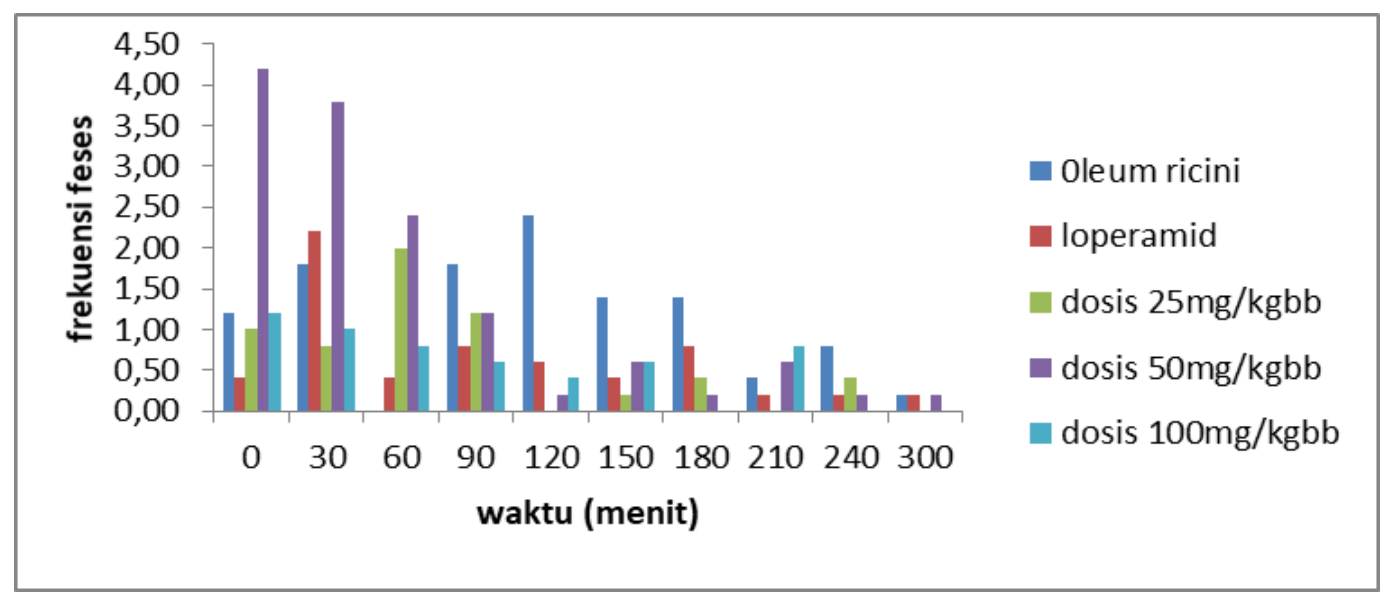

Gambar 1. Frekuensi defekasi dari ekstrak etanol daun suji.

Dari Tabel 5 pada pengamatan frekuensi defekasi, yang menunjukkan perbedaan yang bermakna terhadap kelompok kontrol secara statistik $(p<0,05)$ adalah kelompok yang diberi ekstrak daun suji dosis $50 \mathrm{mg} / \mathrm{kgBB}$. Pada kelompok mencit yang diberikan ekstrak etanol daun suji $50 \mathrm{mg} / \mathrm{kgBB}$ terjadi peningkatan frekuensi defekasi yang signifikan pada menit ke-0, dibandingkan kelompok kontrol negatif.

Pada Tabel 6 dan Gambar 2 dilihat dari konsistensi feses selama 5 jam pengamatan. Kelompok negatif merupakan kelompok kontrol dimana harga konsistensi fesesnya besar yaitu
6,88 artinya tinja yang keluar encer dan berlendir sedangkan loperamid harga rata-rata konsistensi fesesnya 1,00 dimana tinja yang keluar bersifat padat. Pada pengamatan konsistensi feses, yang menunjukan perbedaan bermakna terhadap kelompok negatif yaitu loperamid $2 \mathrm{mg} / \mathrm{kgBB}$, dosis ekstrak etanol daun suji dosis $25 \mathrm{mg} / \mathrm{kgBB}$ dan $100 \mathrm{mg} / \mathrm{kgBB}$. Peningkatan konsistensi feses rata-rata dialami pada menit ke120 setelah pemberian minyak jarak. Perbaikan konsistensi feses bisa disebabkan karena terjadi penurunan motilitas usus besar dan jumlah air yang diserap dari usus besar meningkat. 


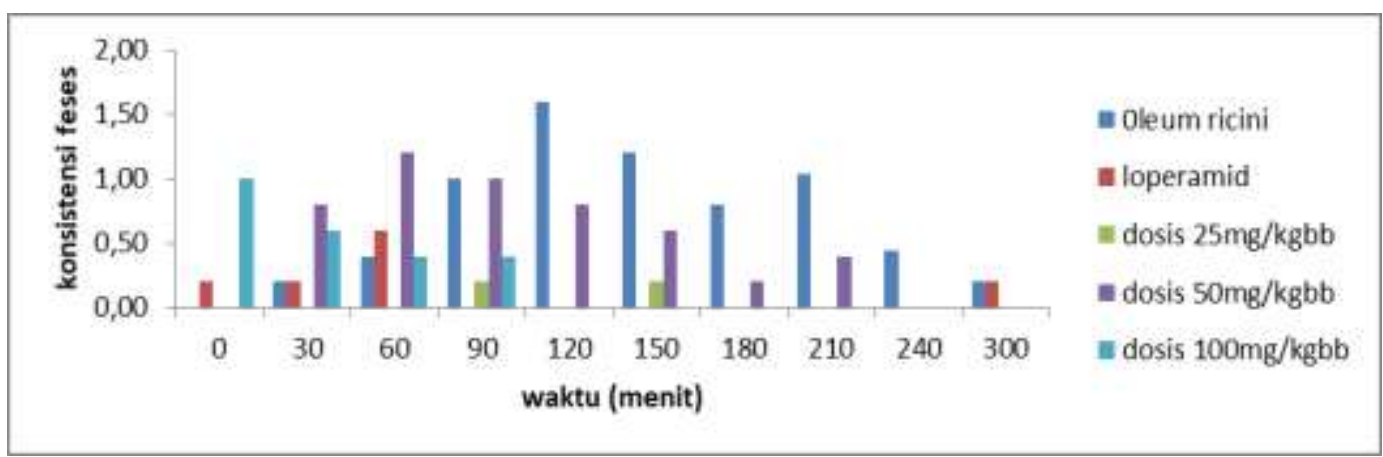

Gambar 2. Konsistensi feses dari ekstrak etanol daun suji.

Pada Tabel 7 dapat dilihat pengamatan berat feses. Kelompok obat yang menunjukkan perbedaan yang bermakna secara statistik terhadap kontrol yaitu ekstrak etanol daun suji dosis $25 \mathrm{mg} / \mathrm{kgBB}$ dan 100 $\mathrm{mg} / \mathrm{kgBB}$ pada menit ke-0 setelah pemberian penginduksi minyak jarak. Pengukuran berat feses tidak bisa secara langsung mengindikasikan diare, karena pengukuran berat feses dapat terganggu apabila mencit tersebut mengalami urinasi. Kecenderungan feses yang lebih berat di menit ke-0 diperkirakan masih terdapat banyaknya massa usus yang bisa didefekasikan dan peningkatan frekuensi defekasi yang terjadi pada pengamatan awal dikarenakan perlakuan awal pada hewan yang membuat hewan uji menjadi stres.

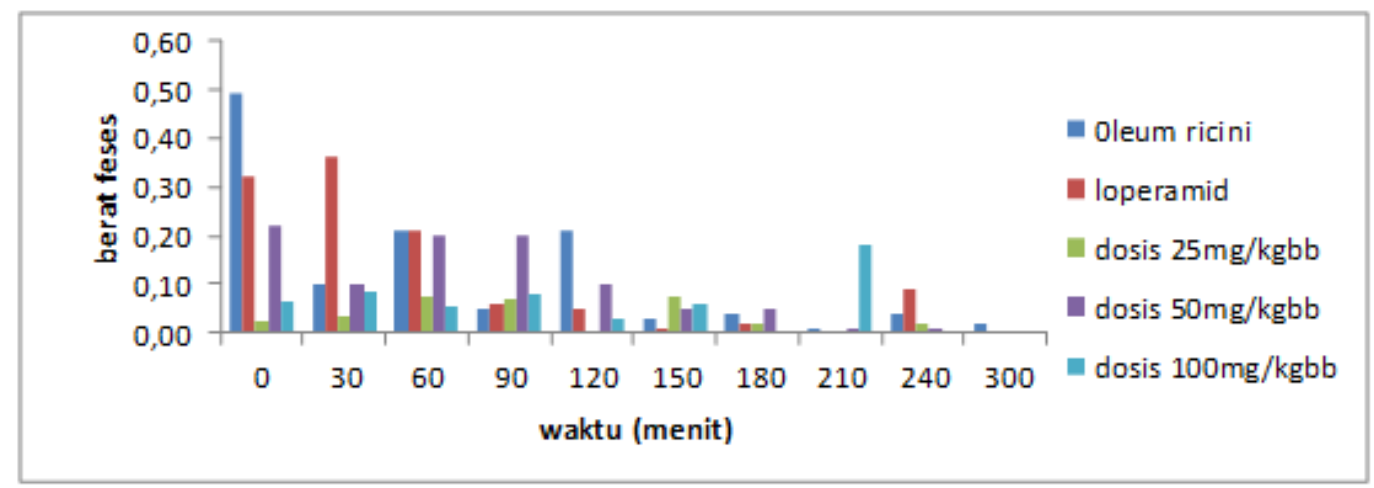

Gambar 3. Berat feses dari ekstrak daun suji. 
Tabel 8. Penurunan relatif lintas usus mencit terhadap kontrol negatif

\begin{tabular}{lcc}
\hline Kelompok & Ratio $(\mathbf{X} / \mathbf{Y})$ & \% Reduksi motilitas \\
\hline Kontrol & $0,49 \pm 0,14$ & - \\
EDS $25 \mathrm{mg} / \mathrm{kgBB}$ & $0,54 \pm 0,19$ & 0,10 \\
EDS $50 \mathrm{mg} / \mathrm{kgBB}$ & $0,50 \pm 0,17$ & 2,04 \\
EDS $100 \mathrm{mg} / \mathrm{kgBB}$ & $0,52 \pm 0,26$ & 6,12 \\
Loperamid 2 mg & $0,34 \pm 0,12$ & $30,6^{*}$ \\
\hline
\end{tabular}

Keterangan: EDS = Ekstrak daun suji.

Pada pengujian efek antidiare dengan metode transit intestinal, yang diamati adalah perbandingan antara panjang usus mencit yang dilalui tinta dan panjang usus mencit keseluruhan. Pada Tabel 8 dapat dilihat bahwa aktivitas penurunan gerakan peristaltik usus yang dihasilkan tidak berbeda bermakna dibandingkan dengan kontrol negatif. Loperamid $2 \mathrm{mg}$ sebagai pembanding. Perbandingan panjang usus yang dilalui tinta dengan panjang usus seluruhnya akan lebih kecil apabila dibandingkan dengan kontrol negatif yang tidak diberi obat.

\section{Kesimpulan}

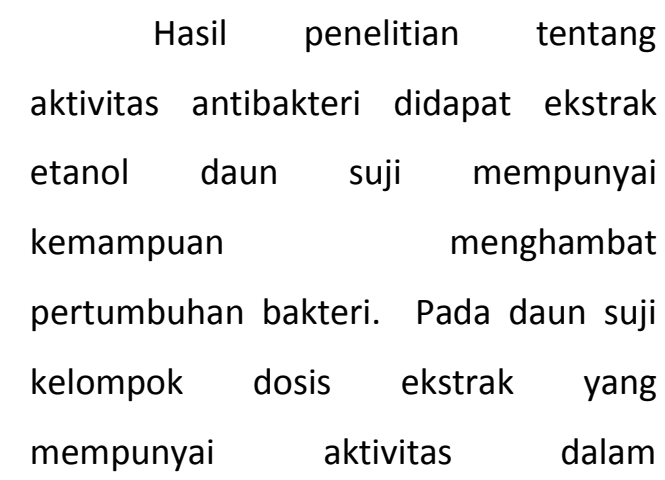

memproteksi diare oleh minyak jarak yaitu dosis $50 \mathrm{mg} / \mathrm{kgBB}$, dosis ini dapat menurunkan frekuensi defekasi secara bermakna, dosis $25 \mathrm{mg} / \mathrm{kgBB}$ dan 100 $\mathrm{mg} / \mathrm{kgBB}$ dapat meningkatkan konsistensi dan menurunkan berat feses.

\section{Daftar Pustaka}

Wells, B.G., DiPiro, J.T., Schwinghammer, T.L., DiPiro, C.V. 2014. Pharmacotheraphy Handbook. New York: Mc Graw Hill Companies.

Ditjen POM, Depkes. 1986. Sediaan Galenik. Jakarta: Departemen Kesehatan Republik Indonesia.

Goodman dan Gilman. 2007. Dasar Farmakologi Terapi. Vol I. Jakarta: EGC.

National Committte for Clinical Laboratory Standars. 2003. Performance Standards of Antimicrobial Suspectibility Testing, $8^{\text {th }} \quad$ Informational Suplements M100 S12 National Committee for Laboratory Standars. Villanova. 
Oswald, T.T., Nurendah, P.S., Dzulkarnain, B. 1982. Komponen tumbuhan yang aktif sebagai antidiare. Prosiding Kongres Nasional XI ISFI, Jakarta.
Sukandar, E.Y., Andrajati, R., Sigit, J.I., Adnyana, I.K., Setiadi, A.P., Kusnandar. 2009. ISO Farmakoterafi. Jakarta: PT ISFI Penerbitan. 